\title{
Egzersiz Yapan Bireylerde Egzersiz Bağımlılığı ve Benlik Saygısı
}

\section{Exercise Addiction and Self-Esteem in Individuals Exercising}

\section{Haşim Katra 1iD}

1. Çanakkale Onsekiz Mart Üniversitesi, Ezine Meslek Yüksekokulu, Çanakkale

\begin{abstract}
Objective: The aim of this study was to determine the exercise addiction level and self-esteem of individuals who exercise, and to examine correlations and differences with different variables.

Method: A total of 202 people exercising in sports centers located in Çanakkale provincial center participated in the research. Data collection tools used in the research included the Exercise Addiction Scale and Rosenberg SelfEsteem Scale.

Results: Gender variable was determined to have no effect on exercise addiction and self-esteem. According to the marital status variable, participants were determined to have significant differences in postponement of individualsocial needs and conflict points. There was a significant correlation identified between the age variable and selfesteem points. Individuals participating in exercise were determined to have a positive significant correlation between frequency of exercise and exercise age with exercise addiction.

Conclusion: Individuals who exercise were a dependent group in terms of exercise addiction and had high selfesteem points, while exercise addiction levels increased with the increase in weekly exercise duration and months of participation in exercise. Additionally, among individuals who exercise, single individuals were concluded to postpone individual and social needs for participation in exercise.
\end{abstract}

Keywords: Exercise, exercise addiction, self-esteem

Öz

Amaç: Bu çalışmada egzersiz yapan bireylerin egzersiz bağımlılık düzeyini, benlik saygılarını belirlemek, farklı değişkenlerle ilişkileri ve farkları ortaya koymak amaçlanmıştır.

Yöntem: Çalışmaya Çanakkale II merkezinde bulunan spor merkezlerinde egzersiz yapan 202 kişi katılmıştır. Araştırmanın veri toplama araçları olarak Egzersiz Bağımlılığı Ölçeği ve Rosenberg Benlik Saygısı Ölçeği kullanılmıştır.

Bulgular: Elde edilen bulgulara göre cinsiyet değişkenin egzersiz bağımlılığı ve benlik saygısı üzerinde etkisi olmadığı belirlenmiş̧tir. Medeni durum değişkenine göre katıımcıların bireysel-sosyal intiyaçlarını erteleme ve çatışma puanlarında anlamlı fark olduğu belirlenmiştir. Yaş değişkeni ve benlik saygısı puanı arasında anlamlı ilişki olduğu tespit edilmiştir. Egzersize katılan bireylerin egzersiz sıkığı ve egzersiz yaşlarının egzersiz bağımlılı̆ıyla pozitif yönde anlamlı ilişkisi olduğu belirlenmiştir.

Sonuç: Egzersiz yapan bireylerin egzersiz bağımlılı̆ı açısından bağımlı grup oldukları ve benlik saygı puanlarının yüksek olduğu, haftalık egzersiz süresi ve egzersize katılım aylarııı artmasılyla birlikte egzersiz bağımlılık düzeylerinin artıı̆ı belirlenmiştir. Bununla birlikte egzersiz yapan bireyler arasında bekar olan bireylerin egzersize katılım için bireysel ve sosyal intiyaçlarını erteleyebildikleri sonucuna varılmışıı

Anahtar kelimeler: Egzersiz, egzersiz bağımlılığı, benlik saygısı 


\section{Giriş}

Egzersiz, planlı, yapılandırımış, tekrarlayıcı fiziksel uygunluğun bir ya da birkaç unsurunu geliştirmeyi amaçlayan sürekli aktivitelerdir (1). Düzenli fiziksel aktivitenin genel sağlığı ve zindeliği iyileştirmeye yardımcı olduğu ve birçok kronik hastalık riskini azalttığı iyi bilinmektedir (2). Berczik ve diğerleri (3) benzer şekilde düzenli fiziksel aktiviteye katılımın sağlığın korunmasında ve hastalıkların önlenmesinde önemli rol oynadığını belirtmiş olup, aşırı egzersizin hem fiziksel hem de zihinsel sağlık üzerinde olumsuz etkileri olabileceğini vurgulamışlardır.

Bağımlılık, alışkanlık oluşturan maddeye zorunlu intiyaç ve kullanımdır (4). Son zamanlarda bağımlıık kavramının içeriğinde değişikler olmuş, öncesinde psikoaktif maddeler ile ilişkilendirilen bağımlık kavramı, günümüzde maddeye dayanmayan ve davranışsal bağımlılıklar olarak adlandırılan yeni kategorilerde karşımıza çıkmaktadır (5). Bazı insanlar için egzersiz, davranışsal bağımlıık kriterlerinin çoğunu karşılayan aşırı ve takıntılı egzersiz modellerine dönüşebilir. Egzersiz bağımılı̆̆g, artan egzersiz miktarı, yoksunluk semptomları, tolerans ve kontrol kaybı ile karakterizedir. Egzersiz bağımlılı̆ı fiziksel ve psikolojik sıkıntıya, sağlığın azalmasına neden olabilir (6). "Bağımlı" egzersiz yapan bireylerin, içsel ödüller için egzersiz yapma ve egzersiz yapamadıklarında rahatsız edici yoksunluk hissi yaşama olasilığı daha yüksektir. Egzersiz yapanlar, sürdürülebilir uzun vadeli fiziksel, psikolojik ve sosyal sağlık sonuçlarına yardımcı olan bir tutumu benimserken bir yandan da bir yaşam dengesi duygusu edinmelidir (7). Szabo ve diğerleri (8) egzersiz bağımlıı̆ııın bilinmesi, tanınması ve her şekilde önlenmesi gereken psikolojik bir hastalık olarak ifade etmiştir.

Brown ve diğerleri (9) benlik saygısını insanların karakteristik olarak kendileri hakkında hissettiklerini ifade etmek için kullanıldığını belirtmiştir. Sosyal bilimlerde benlik saygısı, kişinin kendisinin veya kişiliğinin göze çarpan nitelikleri karşısındaki değerlemelerin toplamı olarak ölçülen varsayımsal bir yapıdır. Bununla birlikte kişinin kendi değer ve öneminin duyuşsal bir değerlendirilmesidir (10). Bu nedenle, benlik saygısı bir enerji rezervuarı ile benzerdir. Benlik saygısı rezervuarı başarıı bir kendini doğrulama ile doldurulur ve kendi kendini doğrulama süreci bozulduğunda tükenir (11). Fox (12) benlik saygısının genel halk arasında anlam kazanmış birkaç psikolojik terimden biri olduğunu, yaşam kalitesi ve zihinsel sağığın önemli bir yönü olarak kabul edildiğini belirtmiştir. Orth ve Robins (13) ergenlik döneminden orta yetişkinliğe kadar benlik saygısının arttığını, 50-60 yaşlarında zirveye ulaştığı ve daha sonrasında yaşılığa doğru azalmaya başladığını belirtmiştir.

Fiziksel aktivite ve egzersizin psikolojik zindeliği geliştirmesi sebebiyle bu alanlarda araştırmalara ilgi artmıştır. Bu bağlamda, benlik algısı zihinsel sağlığın ve bireyin psikolojik fonksiyonlarının bir göstergesi olması sebebiyle egzersiz ile ilişkisi araştıılan psikolojik kavramlar arasında yer almaktadır (14). Egzersize katılımın fiziksel ve zihinsel sağlığa olumlu yönde etkisi bilinmektedir. Bununla beraber egzersize katılan bireylerde egzersize yönelik bağımlıık düzeyi ve zihinsel sağlığın belirleyicilerinden olan benlik saygı düzeyinin belirlenmesi, ilişkilerin ortaya konması önem arz etmektedir. Bu sebeple bu araştırmanın amacı egzersiz yapan bireylerde egzersiz bağımlılı̆ı ve benlik saygısının arasındaki istatiksel ilişkiyi, farklı değişkenler ile egzersiz bağımlıı̆ı ve benlik saygısının gruplar arasındaki farklarını ve ilişkilerini ortaya koymaktır.

\section{Yöntem}

\section{Örneklem}

Çalışma tarama tipi ve ilişkisel tarama tipi araştırmaya uygun şekilde hazırlanmıştır. Araştırmanın çalışma grubunu Çanakkale ilinde hizmet veren fitness spor merkezlerine egzersiz amacıyla katılım sağlayan bireyler oluşturmaktadır. Araştırmada kolayda örnekleme tekniği kullanılmış ve bu sebeple örneklem hesaplaması yapılmamıştır. Araştırmanın veri toplama araçlarını 10 farklı fitness spor merkezinde egzersiz yapan 240 katılımcı yanıtlamıştır. Araştırmanın veri toplama süreci 11-02-2021 ve 11-03-2021 tarihleri arasında gerçekleştirilmiştir. 


\section{İşlem}

Çanakkale II Merkezinde bulunan fitness spor merkezlerinde egzersiz yapan erkek ve kadın toplam 240 katılımcıya veri toplama araçları araştırmacı tarafından maske, mesafe ve hijyen kuralları çerçevesinde yüz yüze uygulanmıştır. Araştırmaya 18 yaş altı bireylerin katılmasında ailelerinden onam alınması gerektiği için 18 yaş altındaki bireyler araştırmaya dahil edilmemiştir. Katılımcıların araştırmaya dahil edilme kriterleri fitness spor merkezlerinde egzersiz yapıyor olmaları ve gönüllü katılım göstermeleridir. Katıımcıların veri toplama araçlarına verdikleri yanıtlarda samimi oldukları varsayılımıştır. Araştırmaya katılan bireylere aydınlatılmış onam formu veri toplama araçlarıyla birlikte sunulmuş, araştırmaya katılımı kabul ettiklerini onaylamışlardır. Katılımcılardan toplanan 240 veri toplama aracına verilen yanıtlarda eksik ve hatalı verilerin olduğu belirlenen 38 katılımcıya ait veri araştırmaya dahil edilmedi. Araştırmaya katılım gösteren

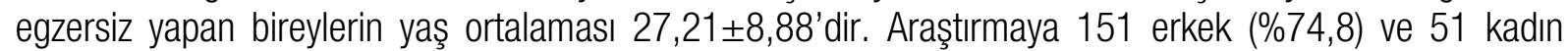
(\%25,2) toplam 202 katılımcının verileri dahil edilmiştir. Çanakkale Onsekiz Mart Üniversitesi Rektörlüğü, Lisansüstü Eğitim Enstitüsü E-84026528-050.01.04-2100021083 sayılı kararıyla çalışmanın etik kurul izni alınmıştır.

\section{Veri Toplama Araçları \\ Demografik Veri Toplama Formu}

Araştırmacı tarafından hazırlanan demografik form yaş, cinsiyet, medeni durum, hafta kaç gün egzersiz yapıyorsunuz?, ne kadar süredir egzersiz yapıyorsunuz ? (Yıl veya ay olarak belirtiniz) şeklindedir. Ne kadar süredir egzersiz yapıyorsunuz? (Yıl veya ay olarak belirtiniz) sorusuna yıl olarak yanıt veren bireylerin yanıtları ay değişkenine çevrilerek verileri giriş yapılmıştır.

\section{Egzersiz Bağımlıığı Öıçeği (EBÖ)}

Demir ve arkadaşları (15) tarafından geliştirilen bununla birlikte geçerlilik ve güvenirlik çalışması gerçekleştirilen Egzersiz Bağımlılı̆ı Ölçeği 17 madde ve 3 alt ölçekten oluşmaktadır. Ölçeğin birinci alt ölçek "Aşırı Odaklanma ve Duygu Değişimi”, ikinci alt ölçek "Bireysel-Sosyal İhtiyaçların Ertelenmesi ve Çatışma", üçüncü alt ölçek ise "Tolerans Gelişimi ve Tutku” şeklindedir. Içeğin geneli için Cronbach Alpha güvenirlik katsayısı 0,88, birinci alt ölçek için 0,83; ikinci alt ölçek için 0,79; üçüncü alt ölçek için 0,77 olarak bulunmuştur. Ölçeğin puanlaması; $1=$ Kesinlikle Katılmıyorum, 2= Kısmen Katımıyorum, 3= Orta Düzeyde Katılmıyorum, 4= Katılıyorum, 5= Kesinlikle Katılıyorum şeklindedir. Puan aralıkları "1-17 normal grup, 18- 34 az riskli grup, 35-51 risk grubu, 52-69 bağımlı grup, 70-85 yüksek düzeyde bağımlı grup" olarak değerlendirilmektedir.

\section{Rosenberg Benlik Saygısı Ölçeği}

Rosenberg (16) tarafından geliştiren ölçeğin Türkçeye uyarlaması Çuhadaroğlu (17) tarafından gerçekleştirmiştir. 63 madden oluşan ölçek 12 alt ölçekten oluşmaktadır. Çalışmamızda Benlik Saygısı alt ölçeği kullanılmıştır. 10 madden oluşan alt ölçek 4'lü likert tipidir. Ölçeğin test-tekrar test güvenirliğinde her alt test için elde edilen güvenirlik katsayıları 0.49 ile 0.89 arasında değişmiştir (16). Ölçeğin değerlendirmesinde puanlama şu şekildedir; 1,2,4,6,7. Maddelerde: Çok doğru=4, Doğru=3, Yanlış=2, Çok yanlış=1 şeklinde, 2,5,8,9,10. Maddelerde: Çok doğru $=1$, Doğru=2, Yanlış=3, Çok yanlış= 4 olarak puanlanmaktadır ve ölçekten elde edilebilecek puanlar 10 ile 40 arasında değişmektedir (18).

\section{Veri Analizi}

Elde edilen veriler SPSS 20.0 istatistiksel analiz programında analiz edilmiş, verilerin normal dağılım göstermemesi sebebiyle (Tablo 2) verilerin analizinde nonparametrik testler kullanılmıştır. Verilerin analizinde değişkenler arasındaki ilişkiyi ortaya koymak amacıyla Spearman Korelasyon analizi, gruplar arasındaki farkları belirlemek amacıyla Mann-Whitney U testi kullanılmıştır. 


\section{Bulgular}

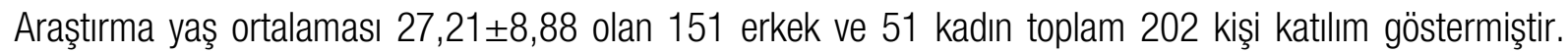
Katıımcılar \%21,3'ü evli (43 kişi) ve \%78,7'si (159 kişi) bekardır. Katılımcılar haftada ortalama 4,31 $\pm 0,90$

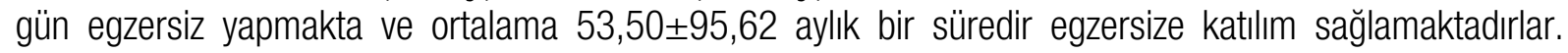
Egzersiz yapan bireylerin egzersiz bağımlıı̆ı ortalama puanı $53,02 \pm 10,77$, egzersiz bağımlılı̆ı alt ölçeklerinden aşıı odaklanma ve duygu değişimi ortalama puanı 26,02 $\pm 5,16$, bireysel-sosyal intiyaçların ertelenmesi ve çatışma ortalama puanı $14,65 \pm 4,47$, tolerans gelişimi ve tutku ortalama puanı $12,34 \pm 3,91$, benlik saygısı puanları ortalama puanı, ise $33,64 \pm 4,22$ olarak belirlenmiştir. Egzersiz yapan bireylerin bağımlı grup olduğu tespit edilmiştir. Egzersiz yapan bireylerin benlik saygısı orta düzeydedir.

Tablo 1. Egzersiz yapan bireylerin yaş değişkeniyle egzersiz bağımlılıkları ve benlik saygıları arasındaki ilişki

\begin{tabular}{|c|c|c|c|c|c|c|}
\hline & Yaş & $\begin{array}{l}\text { Egzersiz } \\
\text { Bağımlilı̆ı }\end{array}$ & $\begin{array}{l}\text { Aşırı Odaklanma ve } \\
\text { Duygu Değişimi }\end{array}$ & $\begin{array}{l}\text { Bireysel-Sosyal } \\
\text { Ihtiyaçların } \\
\text { Ertelenmesi ve } \\
\text { Çatışma }\end{array}$ & $\begin{array}{l}\text { Tolerans } \\
\text { Gelişimi ve } \\
\text { Tutku }\end{array}$ & Benllk Saygısı \\
\hline 1 & 1 & -.020 & 085 & -.118 & -.054 & $224^{* *}$ \\
\hline$p$ & & 0,775 & 0,232 & 0,096 & 0,446 & 0,001 \\
\hline
\end{tabular}

Egzersiz yapan bireylerin yaş değişkenine göre egzersiz bağımlı̆̆̆ı ve benlik saygısı arasındaki ilişkiyi belirlemek amacılya gerçekleştirilen Spearman Korelasyon analiz sonucu Tablo 1'de gösterilmiştir. Buna göre katılımcıların yaş değişkeni ve benlik saygıları arasında pozitif yönde ve orta düzeyde anlamlı ilişki varken $(p<0,05)$, yaş ve egzersiz bağımlııkları arasında anlamlı ilişki yoktur ( $p>0,05)$. Katılımcıların yaş değişkeni ve egzersiz bağımlılığı alt ölçekleri arasında istatistiksel olarak anlamlı ilişki yoktur $(p>0,05)$.

\begin{tabular}{|c|c|c|c|c|c|c|}
\hline & $\begin{array}{c}\text { Haftalık Egzersiz } \\
\text { Günü }\end{array}$ & $\begin{array}{l}\text { Egzersiz } \\
\text { Bağımlılığı }\end{array}$ & $\begin{array}{c}\text { Aşııı } \\
\text { Odaklanma } \\
\text { ve Duygu } \\
\text { Değişimi }\end{array}$ & $\begin{array}{l}\text { Bireysel- } \\
\text { Sosyal } \\
\text { İhtiyaçların } \\
\text { Ertelenmesi } \\
\text { ve Çatışma }\end{array}$ & $\begin{array}{c}\text { Tolerans } \\
\text { Gelişimi ve } \\
\text { Tutku }\end{array}$ & $\begin{array}{l}\text { Benlik } \\
\text { Saygısı }\end{array}$ \\
\hline$r$ & 1 & $146^{*}$ & , $161^{*}$ & ,090 & 116 &,- 037 \\
\hline \multirow[t]{2}{*}{$p$} & & 0,019 & 0,011 & 0,102 & 0,050 & 0,300 \\
\hline & $\begin{array}{c}\text { Egzersiz } \\
\text { Yaptıkları Ay }\end{array}$ & & & & & \\
\hline$r$ & 1 & , 391** & , 412** & ,229** & ,283** &, $147^{*}$ \\
\hline$p$ & & 0,000 & 0,000 & 0,004 & 0,000 & 0,018 \\
\hline
\end{tabular}

Egzersiz yapan bireylerin haftalık egzersiz sıklığı ve egzersiz yaptıkları ay değişkenine göre egzersiz bağımlıı̆̆, alt ölçekleri ve benlik saygısı arasındaki ilişkiyi belirlemek amacıyla gerçekleştirilen Spearman Korelasyon analiz sonucu Tablo 2'de gösterilmiştir. Buna göre katılımcların haftalık egzersiz sıkığı ve egzersiz bağımlıı̆̆ değişkeni arasında istatistiksel olarak pozitif yönde ve düşük düzeyde anlamlı ilişki vardır $(p<0,05)$. Bununla birlikte egzersiz yapan bireylerin haftalık egzersiz sıklı̆ı ve aşııı odaklanma ve duygu değişimi arasında istatistiksel olarak pozitif yönde ve düşük düzeyde anlamlı ilişki vardır $(p<0,05)$. Haftalık egzersiz sıkıı̆ı ve bireysel-sosyal intiyaçları ertelenmesi ve çatışma, tolerans gelişimi ve tutku alt ölçekleri arasında istatistiksel olarak anlamlı fark yoktur $(p>0,05)$. Katılımcıların egzersiz ayları ve egzersiz bağımlılı̆ı değişkeni arasında pozitif yönde ve orta düzeyde anlamlı ilişki vardır $(p<0,01)$. Egzersiz yapan bireylerin egzersiz ayı ve egzersiz bağımlıı̆̆ alt ölçekleri olan aşırı odaklanma ve duygu değişimi, bireyselsosyal intiyaçların ertelenmesi ve çatışma, tolerans gelişimi ve tutku arasında istatistiksel olarak pozitif yönde ve orta düzeyde anlamlı ilişki vardır $(p<0,01)$. Egzersiz yapan bireylerin egzersiz ayları ve benlik saygısı arasında istatistiksel olarak anlamlı ilişki vardır $(p<0,05)$. 
Tablo 3. Egzersiz yapan bireylerin cinsiyet değişkenine göre egzersiz bağımlılı̆ı ve alt ölçekleri, benlik saygısı puanları arasındaki fark

\begin{tabular}{|c|c|c|c|c|c|c|c|}
\hline & Cinsiyet & n & $\begin{array}{c}\text { Sira } \\
\text { Ortalaması }\end{array}$ & $\begin{array}{c}\text { Sira } \\
\text { Toplamı }\end{array}$ & U & Z & $p$ \\
\hline Egzersiz Bağımlılığı & Erkek & 151 & 101,85 & 15379 & 3798,00 &,- 146 & 0,884 \\
\hline Toplam Puan & Kadın & 51 & 100,47 & 5124 & & & \\
\hline \multirow[t]{2}{*}{$\begin{array}{l}\text { Assırı Odaklanma ve } \\
\text { Duygu Değişimi }\end{array}$} & Erkek & 151 & 101,04 & 15257 & 3781,00 &,- 193 & 0,847 \\
\hline & Kadın & 51 & 102,86 & 5246 & & & \\
\hline \multirow[t]{2}{*}{$\begin{array}{l}\text { Bireysel-Sosyal } \\
\text { İhtiyaçların } \\
\text { Ertelenmesi ve } \\
\text { Çatışma }\end{array}$} & Erkek & 151 & 105,34 & 15906,50 & 3270,50 & $-1,612$ & 0,107 \\
\hline & Kadın & 51 & 90,13 & 4596,50 & & & \\
\hline \multirow{2}{*}{$\begin{array}{l}\text { Tolerans Gelişimi ve } \\
\text { Tutku }\end{array}$} & Erkek & 151 & 100,86 & 15230 & 3754,00 &,- 268 & 0,788 \\
\hline & Kadın & 51 & 103,39 & 5273 & & & \\
\hline \multirow[t]{2}{*}{ Benlik toplam puan } & Erkek & 151 & 98,57 & 14884,50 & 3408,50 & $-1,228$ & 0,219 \\
\hline & Kadın & 51 & 110,17 & 5618,50 & & & \\
\hline
\end{tabular}

Egzersiz yapan bireylerin cinsiyet değişkenine göre egzersiz bağımlılı̆ı ve alt ölçekleri, benlik saygısı puanları arasındaki farkı belirlemek amacıyla yapılan Mann-Whitney $U$ testi sonuçları Tablo 3'te gösterilmiştir. Buna göre egzersiz yapan bireylerin cinsiyet değişkenine göre egzersiz bağımlıı̆̆ı puanlarında istatistiksel olarak anlamlı fark yoktur $(U=3798, p>0,05)$. Egzersiz yapan bireylerin cinsiyet değişkenine göre egzersiz bağımlılığı alt ölçekleri olan aşııı odaklanma ve duygu değişimi puanları $(\mathrm{U}=3781)$, bireysel-sosyal intiyaçların ertelenmesi ve çatışması puanları $(U=3270,50)$, tolerans gelişimi ve tutku puanları $(U=3754)$ arasında istatistiksel olarak anlamlı fark yoktur $(p>0,05)$. Egzersiz yapan bireylerin benlik saygı puanları arasında istatistiksel olarak anlamlı fark yoktur $(U=3408,50, p>0,05)$. Cinsiyet değişkenine göre gruplar arasında istatistiksel olarak anlamlı fark yoktur ( $p>0,05)$.

Tablo 4. Egzersiz yapan bireylerin medeni durumlarına göre egzersiz bağımlılığı ve alt ölçekleri, benlik saygısı puanları arasındaki fark

\begin{tabular}{|c|c|c|c|c|c|c|c|}
\hline & $\begin{array}{l}\text { Medeni } \\
\text { Durumu }\end{array}$ & $\mathrm{n}$ & $\begin{array}{c}\text { Sira } \\
\text { Ortalaması }\end{array}$ & $\begin{array}{c}\text { Sira } \\
\text { Toplamı }\end{array}$ & $\mathrm{U}$ & Z & $p$ \\
\hline \multirow{2}{*}{$\begin{array}{l}\text { Egzersiz Bağımlıı̆ı Toplam } \\
\text { Puanı }\end{array}$} & Evli & 43 & 96,90 & 4166,50 & 3220,50 &,- 583 & 0,560 \\
\hline & Bekar & 159 & 102,75 & 16336,50 & & & \\
\hline \multirow{2}{*}{$\begin{array}{l}\text { Aşırı Odaklanma ve Duygu } \\
\text { Değişimi }\end{array}$} & Evli & 43 & 109,34 & 4701,50 & 3081,50 &,- 993 & 0,321 \\
\hline & Bekar & 159 & 99,38 & 15801,50 & & & \\
\hline \multirow{2}{*}{$\begin{array}{l}\text { Bireysel Sosyal İhtiyaçların } \\
\text { Ertelenmesi ve Çatışma }\end{array}$} & Evli & 43 & 85,35 & 3670,00 & 2724,00 & $-2,048$ & 0,041 \\
\hline & Bekar & 159 & 105,87 & 16833,00 & & & \\
\hline \multirow[t]{2}{*}{ Tolerans Gelişimi ve Tutku } & Evli & 43 & 94,83 & 4077,50 & 3131,50 &,- 847 & 0,397 \\
\hline & Bekar & 159 & 103,31 & 16425,50 & & & \\
\hline \multirow[t]{2}{*}{ Benlik toplam puan } & Evli & 43 & 118,92 & 5113,50 & 2669,50 & $-2,209$ & 0,027 \\
\hline & Bekar & 159 & 96,79 & 15389,50 & & & \\
\hline
\end{tabular}

Egzersiz yapan bireylerin medeni durumlarına göre egzersiz bağımlılı̆ı ve alt ölçekleri, benlik saygısı puanları arasındaki farkı belirlemek amacıyla yapılan Mann-Whitney $U$ testi sonuçları Tablo 4'te gösterilmiştir. Egzersiz yapan bireylerin medeni durum değişkenine göre gruplar arasında egzersiz bağımlılığı puanlarında istatistiksel olarak anlamlı fark yoktur $(U=3220,50, p>0,05)$. Egzersiz yapan 
bireylerin medeni durum değişkeni ve egzersiz bağımllığı alt ölçeklerinden aşırı odaklanma ve duygu değişimi alt ölçeğinde gruplar arasında istatistiksel olarak anlamlı fark yoktur (U,03081,50, p>0,05). Bireysel-sosyal intiyaçların ertelemesi ve çatışma alt ölçeğinde medeni durum değişkenine göre gruplar arasında istatistiksel olarak anlamlı fark vardır $(U=2724, p<0,05)$. Buna göre bekar katılımcıların sıra ortalaması puanı (Sıra Ortalaması $=105,87$ ), evli bireylerin sıra ortalaması puanına göre (Sıra Ortalaması $=85,35)$ yüksektir. Egzersiz yapan bireylerin medeni durumuna göre tolerans değişimi ve tutku alt ölçeğinde ise gruplar arasında istatistiksel olarak anlamlı fark yoktur $(U=3131,50, p>0,05)$. Egzersiz yapan bireylerin medeni durumlarına göre benlik saygısı puanları arasında istatistiksel olarak anlamlı fark vardır $(U=2669,50, p<0,05)$. Buna göre evli bireylerin benlik saygısı puanı (Sıra ortalaması=118,92) bekar bireylerin (Sıra Ortalaması=96,79) benlik saygısı sıra ortalaması puanından yüksektir.

\section{Tartışma}

Bu araştırma egzersiz yapan bireylerin egzersiz bağımlılı̆ı ve benlik saygısını incelemek, farklı değişkenler arasındaki ilişki ve farkları ortaya koymak amacıyla gerçekleştirilmiştir. Çalışma Çanakkale il Merkezinde bulunan 10 farkı fitness spor merkezinde 18 yaşında üzerinde olan ve egzersiz yapan bireylerle sınırlıdır. Çalışmada elde edilen veriler fitness spor merkezlerinde egzersiz yapan bireylerin ölçüm araçlarına verdikleri yanıtlarla sınırıdır. Çalışmada incelenen değişkenler veri toplama araçları ve demografik değişkenlere dair formdan elde edilen verilerle sınırıdır.

Katılımcıların cinsiyet değişkenine göre egzersiz bağımlııkları arasında istatistiksel olarak anlamlı fark bulunamamıştır. Bu durumun cinsiyet değişkenine göre karşılaştırmalarda katılımcı sayısının düşük olması ve cinsiyet durumuna göre katılımcı sayıları arasındaki farktan kaynaklandığı düşünülebilir. Bununla birlikte çalışmamızda katıımcıların tamamının egzersiz yapan bireylerden oluşması sebebiyle egzersiz bağımlılı̆ı düzeylerinin cinsiyet değişkeninden etkilenmediği söylenebilir. Literatür incelendiğinde farklı bulguların olduğu görülmektedir. Zmijewski ve Howard (19) gerçekleştirdikleri bir çalışmada kadınların erkeklere oranla egzersiz bağımlılıklarının yüksek olduğunu belirtmişlerdir. Cicioğlu ve diğerleri (20) ise erkek sporcuların egzersiz bağımlılık düzeylerinin kadınlara oranla daha yüksek olduğunu rapor etmişlerdir. Costa ve diğerleri (21) çalışmasında erkeklerin egzersiz bağımlılığının kadınlardan daha yüksek olduğunu belirtmişlerdir.

Katılımcıların cinsiyet değişkenine göre egzersiz bağımlılı̆ı alt ölçekleri olan aşııı odaklanma ve duygu değişimi, bireysel-sosyal intiyaçların ertelenmesi ve çatışma, tolerans gelişimi ve tutku puanları arasında istatistiksel olarak anlamlı fark bulunamamıştır. Egzersiz bağımlıı̆ı toplam puanında olduğu gibi egzersiz yapan bireylerin egzersiz bağımlılı̆ı alt ölçeklerinde de cinsiyet değişkeninin etkisi olmadığı görülmektedir. Tekkurşun-Demir ve Türkeli (22) spor bilimleri fakültesi öğrencileri üzerine gerçekleştirdikleri çalışmada cinsiyet değişkenine göre egzersiz bağımlılık düzeyinin farklıaştığını belirtmiş, erkeklerin egzersiz bağımlılı̆ı puan ortalamalarının kadınlara oranla bireysel-sosyal intiyaçların ertelenmesi ve çatışma ölçeğinde anlamlı düzeyde farklılaştığı, tolerans gelişimi ve tutku alt ölçeğinde erkeklerin puan ortalamalarının kadınlara kıyasla anlamlı düzeyde yüksek olduğunu belirtmiştir. Demirel ve Cicioğlu (23) gerçekleştirdikleri bir çalışmada kadın ve erkeklerin egzersiz bağımlılığı alt ölçeklerinde aşıı odaklanma ve duygu değişimi ile intiyaçların ertelenmesi ve çatışma puan ortalamalarına göre az riskli grupta oldukları, tolerans gelişimi ve tutku alt boyutunda ise normal grupta olduklarını belirtmiştir, cinsiyet değişkenine göre gruplar arasında anlamlı fark olmadığı ve istatistiksel olarak cinsiyet değişkeninin egzersiz bağımlılı̆ı üzerine anlamlı bir etkisinin olmadığını belirtmiştir. Literatür incelendiğinde araştırmamızda elde edilen bulguları destekler nitelikte çalışmalar olduğu gibi, farkı bulguların olduğu görülmektedir.

Egzersiz yapan bireylerin cinsiyet değişkenine göre benlik saygısı düzeylerinde istatistiksel olarak anlamlı fark bulunamamıştır. Atan ve diğerleri (24) gerçekleştirdikleri bir çalışmada üniversitede öğrenim gören sporcu ve sedanterlerin cinsiyet değişkeninin benlik saygısını etkilemediğini belirtmiş̧lerdir. Merdinoğlu ve diğerleri (25) çalışmasında kadınların benlik saygı düzeylerinin erkeklere göre yüksek olduğunu belirtmişlerdir. Benzer şekilde Öner (26) genç yetişkin egzersiz liderleri üzerinde yaptı̆ı bir çalışmada kadınların erkeklere göre benlik saygı puanlarının daha yüksek olduğunu rapor etmiştir. Literatür 
incelendiğinde çalışmamızda elde edilen bulguları destekler sonuçlar olduğu gibi farklı sonuçlarında mevcut olduğu görülmektedir. Bu durum çalışmalarda örneklem gruplarının farklı olmasından kaynaklanabileceği gibi cinsiyet değişkeninin dahil edildiği çalışmalarda değişkenler arasında katılımcı sayısı farkından kaynakladığını düşünülebilir. Ayrıca örneklemin egzersiz yapan bireylerden oluşması sebebiyle cinsiyet değişkeninin egzersiz yapan bireylerde zihinsel sağığın bir belirleyicisi olan benlik saygısı üzerine etkisi olmadığı söylenebilir.

Katılımcıların yaş değişkeni ve benlik saygısı puanları arasında istatistiksel olarak anlamlı ilişki olduğu belirlenmiştir. Bunun sebebi olarak bireylerin yaşı ilerledikçe kendilerini değerlendirme durumlarının olumlu yönde ilerlemesi ve benlik saygılarının yükselmesi olarak yorumlanabilir. Merdinoğlu ve diğerleri (25) çalışmasında katılımcıların yaş değişkeni grupları ve benlik saygıları arasında anlamlı fark olmadığını belirtmişlerdir. Kırkbir (27) ise gerçekleştirdiği çalışmada yaş değişkenine göre grupların benlik saygısı puanlarında anlamlı fark olduğunu belirtmiş̧ir. Yöyen (28) üniversite öğrencileri üzerine gerçekleştirdiği bir çalışmada yaş değişkeninin benlik saygısını etkilemediğini belirtmiştir. Öner (26) gerçekleştirdiği bir çalışmada yaş değişkeni ve benlik saygısı alt boyutlarının ilişkili olduğunu belirtmiştir. Literatür incelendiğinde yaş değişkeni ve benlik saygısı ilişkisinde araştırmamızı sonuçlarını destekleyen çalışmalar mevcutken farklı sonuçların olduğunu görülmektedir. Katılımcıların tamamının egzersiz yapan bireylerden oluşmasına rağmen yaş değişkeninin benlik saygısının artmasında rol oynayan bir değişken olduğu söylenebilir.

Egzersiz yapan bireylerin yaş değişkeni ve egzersiz bağımlılı̆ı puanları arasında istatistiksel olarak anlamlı ilişki bulunamamıştır. Katılımcıların yaş değişkeni ve egzersiz bağımlılı̆ı alt ölçekleri arasında istatistiksel olarak anlamlı ilişki belirlenmemiştir. Bunun sebebi olarak yaş değişkeninin egzersiz yapan bireylerde egzersize yönelik bağımlı olmalarında rol oynamadığı söylenebilir. Cicioğlu ve diğerleri (20) elit düzey sporcular ve spor bilimleri fakültesi öğrencileri üzerine gerçekleştirdikleri bir çalışmada elit sporcuların yaş değişkenleri ve egzersiz bağımlıı̆̆ arasında anlamlı ilişki olduğunu, spor bilimleri fakültesi öğrencilerinin yaş değişkeni ve egzersiz bağımlıı̆̆ı arasında anlamlı ilişki olmadığını belirtmiştir.

Egzersiz yapan bireylerin haftalık egzersiz günleriyle egzersiz bağımlıık puanı arasında istatistiksel olarak pozitif yönde anlamlı düzeyde ilişki olduğu belirlenmiştir. Egzersiz yapan bireylerin haftalık egzersiz gün saygısı arttıkça egzersiz bağımlıı̆̆ının arttığı tespit edilmiştir. Bununla birlikte katılımcıların haftalık egzersiz günleri ile egzersiz bağımlılı̆ı alt ölçeklerinden olan aşııı odaklanma ve duygu değişimiyle istatistiksel olarak pozitif yönde anlamlı ilişki olduğu belirlenmiştir. Bu duruma göre egzersiz yapan bireylerin egzersiz günü arttırarak egzersize yönelik aşırı odaklanma düzeylerinin artırdığı ve egzersize katılımdan keyif aldıkları söylenebilir. Bavılı ve diğerleri (30) tarafından gerçekleştirilen bir çalışmada katıımcıların haftalık egzersiz sıkı̆̆ının bağımlı grubun diğer gruplara göre istatistiksel anlamda daha fazla haftalık egzersiz sıkığına sahip olduğunu belirtmiştir. Costa ve diğerleri (21) egzersiz sıklığın egzersiz bağımlılığının ortaya çıkmasında etkili olabileceğini belirtmiştir.

Egzersiz yapan bireylerin egzersiz yaşı ve egzersiz bağımlılığı puanları arasında istatistiksel olarak pozitif yönde ve anlamlı düzeyde ilişki olduğu belirlenmiştir. Bununla birlikte katılımcıların egzersiz yaptıkları ay değişkeniyle egzersiz bağımlılığı alt ölçekleri olan aşırı odaklanma ve duygu değişimi, bireysel-sosyal intiyaçların ertelenmesi ve çatışma, tolerans gelişimi ve tutku arasında istatistiksel olarak anlamlı ilişki olduğu belirlenmiş̧ir. Egzersiz ayı arttıkça katılımcıların alt ölçeklerden aldıkları puanlar artmaktadır. Bu durum egzersiz yapan bireylerin egzersiz ayı arttıkça egzersize katılıma yönelik odaklanmalarının arttığı, egzersizden keyif aldıkları, günlük temel intiyaçlarını egzersize katıım amacıyla erteleyebildikleri, egzersize yönelik tutkularının arttığı söylenebilir. Bavılı ve diğerleri (30) katılımcıların egzersiz yaşının bağımlı grupta diğer gruplara göre daha yüksek olduğu belirtilmiştir. İlbak ve Altun (31) sedanter olmayan bireyler üzerine gerçekleştirdikleri bir çalışmada egzersiz yılı 1-3 yıl olan grubun diğer gruplara göre egzersiz bağımlılık puanlarının anlamlı düzeyde düşük olduğunu belirtmiştir. Orhan ve diğerleri (32) gerçekleştirdikleri bir çalışmada egzersiz bağımlılığı ortalamalarında egzersiz yaşı, düzenli egzersiz ve haftalık egzersiz sıklı̆ına göre istatistiksel olarak anlamlı farklllk bulunduğunu belirtmiştir. Hausenblas ve Symons (33) egzersize katılım ylı ile birlikte yüksek sıkıkta egzersizin egzersiz bağımlıı̆̆ıla ilişkili olduğunu, Costa ve diğerleri 
(21) spor yaşının egzersiz bağımlılığının ortaya çıkmasında etkili olabileceğini belirtmiştir. Literatür incelendiğinde sonuçların çalışmamızda elde edilen sonuçları destekler nitelikte olduğu görülmektedir. Egzersize yapan bireylerin egzersiz yaşı egzersize yönelik bağımlılı̆ın artmasını tetikleyen değişken olduğu düşünülebilir.

Egzersiz yapan bireylerin egzersiz yaptıkları ay değişkeni ve benlik saygıları arasında istatistiksel olarak anlamlı ilişki olduğu belirlenmiştir. Bu durumun egzersiz yaşı yüksek olan bireylerin yaşlarının da yüksek olma intimalinden ortaya çıkıı̆ı düşünülebilir. Çalışma da yaş değişkeni ve benlik saygısı arasında pozitif ilişki olması bu durumu destekler niteliktedir. Kırkbir (27) gerçekleştirdiği bir çalışmada fitness sporcularının bu sporu ne süredir yaptıklarının benlik saygısı üzerinde anlamlı bir etkisi olmadığını belirtmiştir.

Egzersiz yapan bireylerin medeni durumlarına göre egzersiz bağımlıı̆ı toplam puanları arasında istatistiksel olarak anlamlı fark bulunamamıştır. Bununla birlikte egzersiz bağımlıı̆ı alt boyutu olan aşııı odaklanma ve duygu değişimi ve tolerans gelişimi ve tutku alt boyutunda istatistiksel olarak anlamlı bulunmazken, bireysel-sosyal intiyaçların ertelenmesi ve çatışma alt boyutunda ise istatistiksel olarak anlamlı fark olduğu belirlenmiştir. Buna göre bekar olan bireylerin evli olan bireylere göre bireysel-sosyal intiyaçların ertelenmesi ve çatışma puanları daha yüksektir. Bu durumun bekar bireylerin bireysel-sosyal intiyaçlarını egzersize katılım amacıyla erteleme olasılıklarının evli bireylere göre daha yüksek olduğu, bazı sosyal ve bireysel ihtiyaçlarını egzersiz yapabilmek için erteleyebildikleri söylenebilir.

Egzersiz yapan bireylerin medeni durumlarına göre benlik saygıları puanlarında istatistiksel olarak anlamlı fark tespit edilmiştir. Buna göre evli olan bireylerin benlik saygısı puanı bekar olanlara göre daha yüksektir. Literatür incelendiğinde benzer sonuçların olduğu söylenebilir. Kırkbir (27) fitness sporuyla ilgilenen sporcular üzerine gerçekleştirdiği çalışmasında medeni duruma göre anlamlı fark olduğu ve evli bireylerin benlik saygısının bekar bireylere göre yüksek olduğunu beliıtmiştir. Min (29) çalışmasında katıımcıların medeni durumlarına göre benlik saygllarında anlamlı ilişki olduğunu belirtmiştir. Bunun nedeni olarak evli bireylerin bekar bireylere göre yaşlarının daha ileride olması intimalinden kaynaklandığı düşünülebilir. Çalışmamızda yaş değişkeni ve benlik saygısı arasındaki ilişkide bu durumu desteklemektedir.

Sonuç olarak egzersiz yapan bireylerin egzersiz bağımlılıkları ve benlik saygısı puanları incelendiğinde egzersiz bağımlııkların yüksek olduğu ve bağımlı grup oldukları, bunun birlikte benlik saygısı puanlarının yüksek olduğu belirlenmiştir. Egzersize katılım benlik saygısının artmasında etkili bir unsurdur. Egzersiz yapan bireylerde egzersiz sıklığı ve egzersiz yaşının egzersiz bağımlılığının artmasıyla ilişkili olduğu sonucuna varımıştır. Daha yüksek örneklem sayılara ulaşarak benzer çalışmanın yapılması, egzersiz bağımlı̆̆g ve benlik saygısının değişim durumunu daha iyi anlayabilmek amacılla sedanter bireylerle gerçekleştirilecek egzersiz müdahaleleri ile birlikte araştıııması, farklı egzersiz türleri arasında egzersiz bağımlıı̆̆ ve benlik saygısının araştırıması önerilebilir.

\section{Kaynaklar}

1. Özer MK. Fiziksel Uygunluk. 2.Baskı, Ankara: Nobel Yayın Evi, 2006.

2. Chen W. Frequent exercise: a healthy habit or a behavioral addiction? Chronic Dis Transl Med 2016; 2(4): 235240.

3. Berczik K, Szabo A, Griffiths MD, Kurimay T, Kun B, Urban R, Demetrovics Z. Exercise addiction: sysmtoms, diagnosis, epidemiology, and etiology. Substance Use Misuse 2012; 47(4): 403-417.

4. Hesse M. What does addiction mean to me. Mens Sana Monogr 2006; 4(1): 104-126.

5. Nazlıgül MD, YıImaz AE. Oyun bağımlıı̆ı̆ı ve egzersiz bağımlıı̆ı̆na davranışsal bağımlıık çerçevesinden bakış. Bağımlılık Dergisi 2019; 20(2): 97-108.

6. Lichtenstein MB, Hinze CJ. Exercise addiction. Essau CA, Delfabbro PH, (Editörler), Adolescent addiction. Academic Press 2020; 2.Baskl: 265-290.

7. Landolfi E. Exercise addiction. Sports Med 2013; 43(2): 111-119.

8. Szabo A, Griffiths MD, Marcos RLV, Mervo B, Demetrovics Z. Methodological and Conceptual limitations in exercise addiction research. Yale J Biol Med 2015; 88(3): 303-308. 
9. Brown JD, Dutton KA, Cook KE. From the top down:self-esteem and self-evualation. Cogn Emot 2001; 15(5): 615-631.

10. Blascovich J, Tomaka J. Measures of self-esteem. Robinson JP, Shave PR, Wrightsman LS (Editörler). Measures of personality and social psychological attitudes. Academic Press 1991; 115-160.

11. Cast AD, Burke PJ. A theory of self-esteem. Social Forces 2002;80(3):1041-1068.

12. Fox KR. The effects of exercise on self-perceptions and self-esteem. Biddle. S, Fox. KR, Boutcher. SH (Editörler). Physical activity and psychological well-being. London: Routledge, 2000; 88-117.

13. Orth U, Robins RW. The development of self-esteem. Curr Dir Psychol Sci 2014; 23(5): 381-387.

14. Aşçı H. Benlik algısı ve egzersiz. Spor Bilimleri Dergisi 2004; 15(4): 233-266.

15. Demir GT, Hazar Z, Cicioğlu Hi. Egzersiz bağımlıı̆ı ölçeği (EBÖ): Geçerlik ve güvenirlik çalısması. Kastamonu Eğitim Dergisi 2018; 26(3): 865-874.

16. Rosenberg M. Society and the adolescent self-image. Princeton, NJ: Princeton University Press 1965.

17. Çuhadaroğlu F. Adölesanlarda benlik saygısı. Yayınlanmamış Uzmanlık Tezi, Ankara: Hacettepe Üniversitesi Tıp Fakültesi, Psikiyatri Anabilim Dalı, 1986.

18. Oğurlu U. Düşünsel Duygulanımcı Davranış Terapisi (DDDT) odaklı grupla psikoloijk danışmanın ergenlerdeki benlik saygısı düzeyine etkisi. Yüksek Lisans Tezi, Mersin: Mersin Üniversitesi Sosyal Bilimler Enstitüsü, Psikolojik Danışmanlık ve Rehberlik Bilim Dalı, 2006.

19. Zmijewski CF, Howard MO. Exercise dependence and attitudes toward eating among young adults. Eat Behav 2003; 4(2): 181-195.

20. Cicioğlu Hi, Tekkurşun-Demir G, Bulğay C, Çetin E. Elit düzeyde sporcular ile spor bilimleri fakültesi öğrencilerinin egzersiz bağımlılı̆ı düzeyleri. Bağımlılık Dergisi 2019; 20(1): 12-20.

21. Costa S, Hausenblas AH, Oliva P, Cuzzocrea F, Larcan R. The role of age, gender, mood states and exercise frequency on exercise dependence. J Behav Addict 2013; 2(4): 216-223.

22. Tekkurşun-Demir G, Türkeli A. Spor bilimleri fakültesi öğrencilerinin egzersiz bağımlılı̆ı ve zihinsel dayanıklılık düzeylerinin incelenmesi. Spor Bilimleri Araştırmaları Dergisi 2019; 4(1): 10-24.

23. Demirel HG, Cicioğlu Hi. Üst Düzey Sporcuların egzersiz bağımlılık düzeylerinin incelenmesi. Gaziantep Üniversitesi Spor Bilimleri Dergisi 2020; 5(3): 242-254.

24. Atan T, Ünver Ş, Allahverdi E. Üniversitede öğrenim gören sporcuların ve sedanterlerin benlik saygısı düzeylerinin karşılaştııılması. CBÜ Beden Eğitimi ve Spor Bilimleri Dergisi 2018; 13(1): 125-135.

25. Merdinoğlu A, Gürsoy R, Hazar K, Dallı M. Analysis of body perception and self-esteem values connected with aerobic exercise in female and male adults. Niğde Üniversitesi Beden Eğitimi ve Spor Bilimleri Dergisi 2017; 11(3): 333-339

26. Öner Ç. Genç yetişkin egzersiz liderlerinin benlik saygıları ve psikolojik dayanıkllıklarının incelenmesi. Spor Eğitim Dergisi 2019; 3(2): 121-136.

27. Kırkbir H. Fitness sporu ile ilgilenen sporcuların benlik saygısı düzeylerinin incelenmesi. Yüksek Lisans, Rize: Recep Tayyip Erdoğan Üniversitesi Sağlık Bilimleri Enstitüsü, Beden Eğitimi ve Spor Anabilim Dall, 2019.

28. Yöyen E. Üniversite öğrencilerinin benlik saygısı ve yalnızlık düzeylerinin incelenmesi. Kastamonu Eğitim Dergisi 2017; 25(6): 2185-2198.

29. Min SY. Depression, self-esteem, and quality of life in a community. J Korean Acad Psychiatr Ment Health Nurs 2010; 19(1): 1-10.

30. Bavlı Ö, Kozanoğlu ME, Doğanay A. Düzenli egzersize katılımın egzersiz bağımlıı̆̆ üzerine etkisi. Selçuk Üniversitesi Beden Eğitimi ve Spor Bilim Dergisi 2011; 13(2): 150-153.

31. İlbak I, Altun M. Sedanter olmayan bireylerin egzersiz bağımlığı düzeylerinin incelenmesi. ÇOMÜ Spor Bilimleri Dergisi 2020; 3(1): 11-19.

32. Orhan $S$, Yücel AS, Gür E, Karadağ M. Spor merkezlerinde egzersiz bağımlılığının incelenmesi. Turkish Studies 2019; 14(2): 669-678.

33. Hausenblas HA, Downs DS. Exercise dependence: A systematic review. Psychol Sport Exerc 2002; 3(2): 89123. 